\title{
Explaining Disease: \\ A Chapter in Nigerian Historiography
}

\section{Olukayode A. Faleye}

Edo State University, Uzairue

\begin{abstract}
This article examines the issue of historical utility with a focus on the contributions of the sub-fields of environmental and medical history to the development of Nigerian historiography. First, the article maps out the place of Nigerian historiography in 'glocal' view. It proceeds to evaluate the notion of universality embodied in the 'scientification' of historical reality through theoretical expositions. Underpinned by the explanatory dichotomies that project theoretical divisions along the Western triumphalist paradigm, racist-Afrocentric category, and the emerging critical synthesis, it concludes that the latter embodied in the plurality and multidisciplinary narrative of disease pathology unveils alternative pathway for utilitarian Nigerian historiography.
\end{abstract}

Keywords: disease processes, environmental history, historical epidemiology, historical utility, medical history, Nigerian historiography.

\section{INTRODUCTION}

This article offers analytical clarifications for researching public health and disease processes within the subfields of environmental and medical history with a reflection on Nigerian historiography. It particularly focuses on the contribution of the historical explanation of disease to the writing of Nigerian history. This article is organised into four sections. The first is this introductory section. While the second section discusses the place of Nigerian historiography within the 'glocal' trend of modern historical writing, the third section focuses on the contribution of the sub-fields of environmental and medical history to Nigerian historiography from the dimension of public health and historical utility. The final section summarizes the analyses and concludes the study.

Social Evolution \& History, Vol. 20 No. 1, March 2021 94-113

(C) 2021 'Uchitel' Publishing House

DOI: $10.30884 / \mathrm{seh} / 2021.01 .04$ 


\section{NIGERIAN HISTORIOGRAPHY IN 'GLOCAL' PERSPECTIVE}

The institutionalization of the Western experience through colonialism in Africa illustrates an aspect of globalization. However, whenever this movement is seen from the contiguity of 'global' and the 'local', the term 'glocalization' seems more appropriate (Robertson 1995). In essence, the historiographical transition and the changes in the disease environment in an interconnected world transcend hegemonic 'globality' to an interactive complexity welding the 'global' to the 'local'. This conception is particularly useful for the explanation of disease in Nigerian historiography.

The twentieth century was an age of trouble for the historical discipline at the global level. This is the case of a slowly adaptive discipline in the face of drastic epistemological changes in the arts and sciences. This phenomenon obliterated the sacred position of historical scholarship in the borderland of the arts and sciences. Indeed, as the disciplinary boundaries became well defined in the late nineteenth century, the 'epistemologically neutral middle ground that supposedly exists between art and science' disappeared. It has been noted that 'everywhere there is resentment over what appears to be the historian's bad faith in claiming the privileges of both the artist and the scientist while refusing to submit to critical standards currently obtaining in either art or science' (White 1966: 111-112). In essence, the 'undisciplined' epistemological foundation of historical writing that negotiates a space between nineteenth-century arts and sciences projects a dubious disciplinary orientation that casts doubt on historical utility by the onset of the twentieth century.

While the reality of historical bankruptcy steered the face of historians in Europe and America in the late nineteenth and early twentieth centuries, modern history, as a product of the formally and professionally trained historian, was undergoing an epistemological change in Nigeria and Africa under colonial rule. This is the case of the conflict of sources in colonial Nigeria - an intellectual struggle that extended the boundary of modern history as defined by the European historical tradition to include African History with its uniqueness of sources. Thus, the Nigerian historiography was founded on eclectic sources derived from oral tradition and the written Arabic chronicles, the European travellers' accounts and official archival colonial records. These conventional sources symbolize the heterogeneous nature of the Nigerian state and its experience of colonization across the Sahel-Sahara as well as the Atlantic. For instance, oral tradition is instituted in every 
Nigerian community through memories of the past passed between generations. The interaction between Northern Nigeria and Arabian culture across the Sahara instituted written Arabic tradition of which the Kano chronicles is a witness (Falola 1981). The incursion of European travellers and adventurers in some coaster communities of Southern Nigeria led to the written documentation of some activities in the area prior to colonial rule. The colonial era was a landmark in the institutionalization of official documentation of the activities of British administrators in Nigeria. The diverse origin and often distinct orientation of these historical traditions triggered a conflict of sources within Nigerian historiography during the colonial era.

However, being a cultural product, the sources of Nigerian history project distinct lapses. For instance, the oral traditions served as legal evidence of their communities. Hence, it has been criticized for its susceptibility to distortion as a result of memory loss or political propaganda as well as its lack of an absolute dating system. The Arabic sources have been undermined for their overbearing stance on religious activities and appraisal of legendary figures of precolonial Hausa and Kanuri lands. Also, the writings of early European travellers such as Duarte Pacheco Pereira, Joao de Barros, Duarte Pires, and John Adams among others appear to be engrossed in trading activities without adequate mastery of the local languages and cultures. Further, the colonial archival accounts are seen as biased towards the interest of European administrators in colonial Nigeria (Falola 1981). This problem of sources called for a more rigorous approach to Nigerian historiography. Advancing the varieties of historical sources, archaeology was introduced into Nigeria in the colonial era (Shaw 1963). Even though being European in origin, the archaeological excavation of Nok, Ife, Benin, and Igbo Ukwu reinforces the historical evidence in oral tradition, thereby showcasing the benefit of a multidisciplinary approach to the writing of Nigerian History. Moreover, as shown by Faleye (2018a) as well as Faleye and Akande (2019), the native language print archives (vernacular press) provide rare insight into African discourses on public health in colonial Nigeria.

In a way, the evolution of Nigerian history in the colonial era with its Afrocentric tradition became useful immediately for the nationalist struggle for political independence. The deployment of Nigerian historiography against colonialism was operational in separating the Nigerian historical scholarship from the global epistemological challenges of the twentieth century. It is not surprising, therefore, that the discipline before independence drew the attention and admiration of the society, especially scholars and the emerging political elites. Indeed, 
the historical discourse of this era eulogizes Nigerian heritage (Adeoye 1992). It painted Africa as an important stakeholder in the world civilization and dispatched arsenals of intellectual fecundity against colonial rule in Nigeria. This scenario is evidenced by Samuel Johnson's History of the Yorubas (1921) and Kenneth Onwuka Dike's Trade and Politics in the Niger-Delta (1956). This appears to have been consolidated in the 1960s and early 1970s in such works as The Small Brave City State: A History of Nember-Brass in the Niger-Delta (Alagoa 1964); Yoruba Warfare in the Nineteenth Century (Ajayi and Smith 1964); The International Boundaries of Nigeria, 1885-1960: The Framework of an Emergent African Nation (Anene 1970) and The New Oyo Empire: Indirect Rule and Change in Western Nigeria, 1894-1934 (Atanda 1973) and others. Hence, the Nigerian historiography became a tool of national consciousness and an intellectual canon of the natives (Falola and Aderinto, 2010). Consequently, the discipline enjoyed state support at independence. However, in postcolonial Nigeria, the crisis of the state in the form of political instability characterised by military coups, civil war, and economic challenges called for a new Nigerian historiography.

Amidst economic difficulties and political tensions, history as a tool of administration appears to have threatened the new power brokers in Nigeria by the late 1970s. The tenet of the discipline in revealing the truth, perhaps about the contemporary ugly-past of a fragile postcolonial state, seems to have called for caution. Thus, questions were raised about the validity and usefulness of history as a tool of nation-building. These queries imply the informalization of the discipline as the ruling elites who benefitted from the anti-colonial struggle seek to consolidate power through historical bankruptcy. In essence, starting from the $1980 \mathrm{~s}$, the discipline was left to survive based on its epistemological relevance in the Nigerian state. This phenomenon threw the field of Nigerian History into the global space of the disciplinary turbulence. Unfortunately, the addiction of Nigerian historiography to the nineteenth-century empiricism school of historical narrative became dysfunctional in the face of the advances of sciences in the twentieth century. Indeed, due to its static methodological orientation that differs from epistemological changes in the arts and sciences, Nigerian history could no longer claim the role of a borderland discipline between the arts and the sciences. As was elsewhere in the world, this orphanage status isolated the discipline in scholarly discourse. Consequently, this aroused furious criticisms on the usefulness of the discipline in Nigerian society. 
The Nigerian historiography was a latecomer into the furnace of anti-historical discourse in the global space. Indeed, scholars have been worried about the perceived 'dubious' epistemological terrain in which the historical craft thrived. As observed by Hayden White, the hostility towards historical scholarship can be traced to the late nineteenth century in the works of Nietzshe - The Birth of Tragedy (1872) and The Use and Abuse of History (1874). In these works, Nietsche observed the incompatibility of the historical explanation with either the modern arts or the sciences, thereby constituting a nuisance value in intellectual discourse (White 1966). The subjectivity of the historian and his artfulness of manipulating methods and source materials for partisan reasons undermine the pragmatic usage of historical writing in societies. As observed by Edward Hallett Carr, the falsehood of the 'nineteenth-century heresy [affirmed] that history consists of the compilation of a maximum number of irrefutable and objective facts.' Carr noted that 'anyone who succumbs to this heresy will either have to give up history as a bad job and take to stamp-collecting or some other form of antiquarianism or end in a madhouse.' Writing in 1961, Carr asserts that 'it is this heresy which during the past hundred years has had such devastating effects on the modern historian, producing... a vast and growing mass of dry-asdust factual histories' (Carr 1961: 14-15). It has been noted that historiography exemplifies 'prejudice' that justifies groups' hegemonic claims - a consciousness that suggests a progressive history in tandem with group interests around the world (White 2014; Cohn 1996; DirkMoses 2005a). This development exemplifies the nationalist 'revisionism' that projects historical denial, and create narratives that aided or denies violent conflicts and marginalization of peoples around the world (Dirk-Moses 2005a; Bentrovato et al. 2016). This manifestation of factual reductionism makes history an embodiment of contradictory historical theories.

The criticism of historical accounts for its plurality arose from the universality drive in the sciences. The role of science as the intellectual base of European colonialism shows that to 'understand science fully requires an understanding of the ecology of its environment' (Reingold and Rothenberg 1987: XII). This has been demonstrated by the patronage of 'scientists and sciences whose activities served or promised to serve the direct economic and political goals of imperialism' by the colonial bureaucracy (Pyenson 1993: 104). Indeed, it is observed that 'for most of humanity, the history of science and imperialism is the history of science' (Palladino and Worboys 1993: 101102). This is particularly the case of the universality of the scientific approach that crosses culture areas (Pyenson and Pyenson 1999). In 
essence, colonial science was the intellectual medium and machinery that validated and instituted European imperialism in Nigeria and elsewhere in Africa. This intellectual imperialism built on the 'universality' bedrock of scientific knowledge and the Eurocentric theoretical leaning marginalises the African reality and preferences. Indeed, the 'institution of science,' even though useful, 'registered views of nature and race that sustained prejudice' (Macleod 1993: 123). This is particularly true in the case of the bubonic plague in colonial Lagos and elsewhere in Africa where indigenous interventions were underarticulated and scientific roles exaggerated in the official narrative (Faleye and Akande 2019). Notwithstanding, beyond the Afrocentric theory of destructive colonialism, the European administrators using scientific knowledge struggled to address the ecological factors sustaining infectious diseases in the colony from the late 1920s (Faleye 2017; 2018a). Thus, 'unnecessary and usually counter-productive... are inflexible definitions of science, imperialism, capitalism, racism, nationalism and so on' (Pyenson 1993: 106).

The "scientification" of knowledge, that is, an attempt to make disciplines more scientific gained momentum since the second half of the nineteenth century. This phenomenon has been traced to the 'commanding belief in the power of science and technology to solve the manifold problems of society' (Bell 2005: 549-550). Hence, science became a rational engine of governance. However, the projection of an absolute knowledge whether in the natural or social sciences is cultural imperialism, since science itself is a cultural product. In the co-production of disease environment through the instrumentality of the conjoining medical knowledge and urban planning, the incursion of the pre-bacteriological dictates into the bacteriological urban spaces of colonies exemplify the socio-spatial disparity between the centre and periphery of the European Empires in the late nineteenth and early twentieth centuries (Gandy 2006a, 2006b, 2008). It is within this circumstance that sociospatial inequality and incoherent public health practices thrived in the colonies with serious health implications (Home 1938, 1990, 2013). This phenomenon seems to explain the differentiation in public health experiences of the metropole and the margin in a capitalist world. In this way, science appears to have been operationalised as a colonial identity that reinforces marginality in the peripheries of the international political and economic system. In the post-colonial era, the contingency of sciences, especially social sciences in the 'structured language of control, coordination, and cooperation' underpinned the Eurocentric development theories. This ensured that the "policy for development is expressed principally in eco- 
nomic terms, in which [natural] scientific and technological assistance have an instrumental but subsidiary role' (Macleod 1993: 148). The intersection of sciences and governance in post-colonial Africa has been traced to the developmental crisis fostered by the endurance of the Eurocentric social science theories in African public policy. This is the phenomenon Claude Ake (1979) captioned as 'Social Science as Imperialism'. This implies the metamorphoses of European imperialism from colonial natural science to post-colonial social science (Faleye 2020b). It is against this background that the decolonization of knowledge in post-colonial Africa found succour in the moralizing arts as the last hope of deinstitutionalizing the African reality from the rationality of the Eurocentric natural and social sciences.

The hope in the arts to resolve the knowledge dilemma has led to the polarization of historiography in line with the scientific and moralistic approaches. This dilemma has resulted in the multi-narrative of the same events often with the temptation to suppress some pieces of evidence in the discursive reconstruction of historical reality. Nevertheless, historiography provides an alternative to the crisis of knowledge production for good governance in Nigeria and elsewhere in Africa. It has been observed that the historical discipline like other fields in the 'humanities, retains its usefulness for life by incarnating a form of knowledge developed, ideally, by symmetrical inter-subjectivity' (Dirk-Moses 2005b: 347). As Dirk-Moses puts it:

In a world in which rival historical mythologies terrorize people in the name of taming the past and present, the way historians go about making and redeeming validity claims offers an alternative... The temptation may be strong for historians to defend or avenge their people, but by virtue of their discipline they are also members of an international community of scholars that subscribes to a culture of critical discourse: they make claims to which everyone could ideally assent, not just the comparatively small circle of their own group (Dirk-Moses 2005b: 347).

The 'historical is the ethical' since it is based on a search for the truth by incorporating 'uncomfortable facts and rival interpretations' from which individuals could make choices on matters of life and death (Dirk-Moses 2005b: 346-347). Even though Dirk-Moses (2005b) proposes that history could be ethical and also moral. In the context of the interplay of ethics and morality in historiography, Hayden White rightly noted that the historical is ethical because it differentiates 'what... was the case and what ought to... have been, ... not 
morality that, on the basis of some dogmatism insists on telling us what we must and must not do in a given situation of choice' (White 2005: 338). Hence, the disdain for morality in historiography is a fundamental framework to avoid infusing personal values into historical analysis.

In essence, a historian reconstructs the past in an encompassing way that builds on tangible evidence with a bearing on historical utility in society (White 2014: 433). Thus, by presenting redemptive and bridging narratives, 'the historical is the ethical,' thereby instrumental in stopping genocides, racism, and 'imperial wars of domination' (Dirk-Moses 2005a: 328-330). In this way, history is hashed as an 'intellectual activity which is at once poetic, scientific and philosophical in its concerns' (White 2014: XII; Dirk-Moses 2005a: 313). Considering its multidisciplinary nature, the historical arguments must reflect the moderation of theoretical expositions with tangible evidence. The emerging subfields of environmental and medical history within Nigerian historiography incorporate this approach. In this way, history not only embodies the arts, social and natural sciences, but it also polices these disciplines.

\section{RETHINKING NIGERIAN HISTORIOGRAPHY: INSIGHTS FROM THE HISTORICAL THEORIES OF DISEASE PROCESSES}

In the search for historical utility, the early twenty-first century witnessed vigorous attempts by professional historians in Nigeria to reenergize the discipline for the sake of nation-building. In this light, the endowment of historical knowledge as a compass for national peace and development in the face of emerging challenges of insecurity, poor governance and corruption was re-affirmed. The re-fusion of the historical scholarship with the state appears to have yielded some results as the government made 'history' a compulsory unit in primary and secondary school education. However, this amounts to hiding the epistemological challenges in the discipline through the instrumentality of state power.

What more? Beyond the statist approach, the epistemological transformation of the Nigerian historical profession to reflect societal relevance in the age of globalization witnessed a new emphasis on international studies at the tertiary educational level. This has led to the change of the nomenclature and curriculum of the Bachelor programmes in most Nigerian Universities from the typical Bachelor of Arts in History programme to the Bachelor of Arts in History and International Studies/Diplomatic Studies/Strategic Studies. While arguments 
have been made on the overly historical approach to the new nomenclatures, the newly combined honours imply an increased engagement of Nigerian historians with theoretical approaches of social science. This epistemological leaning that emphasized 'international studies' within the Nigerian historical scholarship is a quest for historical utility in the age of the Chinese ascension, south-south cooperation, regional reconfiguration of power and global terrorism.

Indeed, ample historical works reflect the reality of the growing emphasis on international studies in the writing of Nigerian history since the late twentieth and the early twenty-first centuries. Among others, these studies include Bolade M. Eyinla's 'The ODA Charter and changing objectives of Japan's aid policy in Sub-Saharan Africa' (1999); 'The Tokyo Agenda for Action: A Review of Japan's New Strategy on African Development' (2000); 'Beyond Cairo: Emerging Pattern of Euro-African Relationship' (2004); Abimbola O. Adesoji's 'Globalization of the Media and the Challenges of Democratisation in Nigeria' (2006); Sola Akinrinade, and Olukoya Ogen's 'Globalization and De-industrialization: South-South Neo-liberalism and the Collapse of the Nigerian Textile Industry' (2008); Olukayode A. Faleye's 'Africa and International Relations Theory: Acquiescence and Responses' (2014); 'Regional Integration from 'Below' in West Africa: A Study of Transboundary Town-Twinning of Idiroko (Nigeria) and Igolo (Benin)' (2016); 'International Relations Theory: Comparative Reflections on EU-Africa Relations' (2020b); Richard Olaniyan and Rufus T. Akinyele's edited volume Nigeria's Ungoverned Spaces: Studies in Security, Terrorism and Governance (2016).

The burden of the contemporary historians as Hayden White noted 'is to re-establish the dignity of historical studies' in tandem with the 'aims and purposes of the intellectual community at large', that is, to liberate the 'present from the burden of history' (White 1966: 124). To this end, it seems the emergence of alternative epistemological pathways in environmental and medical history comes with innovative interpretation, investigation and representation of historical evidence that promise a meaningful transition in Nigerian historiography in the twenty-first century.

In the search for historical utility in a world bedevilled with the globalization of infectious diseases and environmental challenges, there has been an emerging engagement of Nigerian historians with the study of disease processes and their impact on Nigerian society. This is an attempt to complement the biomedical analysis of diseases in Nigeria, which is often weakly footed. As James L. A. Webb puts it, "the biomedical understandings of disease processes in Africa... 
lack political, social, cultural and economic historical contexts. Africanist historians can develop these historical contexts in ways that will be relevant to the practice of public health in Africa' (Webb 2013: 10). Here, Webb did not call for the historical study of diseases for the sake of history but societal utility in the present. Indeed, the historical lessons of health interventions and local responses could inform contemporary public health policies and strategies in an era of emerging infectious diseases.

The bourgeoning literature on the history of disease and health in Nigeria includes Spencer H. Brown's 'Public Health in Lagos, 18501900: Perceptions, Pattern, and Perspectives' (1992) and 'A tool of Empire: The British Medical Establishment in Lagos, 1861-1905' (2004); Ayodeji Olukoju's 'Population Pressure, Housing and Sanitation in West Africa's Premier Port-City: Lagos, 1900-1939' (1993); Saheed Adeniyi Aderinto's 'Dangerous Aphrodisiac, Restless Sexuality: Venereal Disease, Biomedicine, and Protectionism in Colonial Lagos' (2012); Tunde Oduwobi's 'Tackling Leprosy in Colonial Nigeria, 1926-1960' (2013); Liora Bigon's 'Bubonic Plague, Colonial Ideologies, and Urban Planning Policies: Dakar, Lagos, and Kumasi' (2015); Jimoh Mufutau Oluwasegun's 'Managing Epidemic: The British Approach to 1918-1919 Influenza in Lagos' (2015) and 'The British Mosquito Eradication Campaign in Colonial Lagos, 1902-1950' (2017); Oluwatoyin Babatunde Oduntan's 'Culture and Colonial Medicine: Smallpox in Abeokuta, Western Nigeria' (2016); Olukayode A. Faleye's 'Environmental Change, Sanitation and Bubonic Plague in Lagos, 1924-31' (2017), 'Plague and Trade in Lagos, 1924-1931' (2018a), as well as Olukayode A. Faleye and Tanimola M. Akande's "Beyond "White Medicine": Bubonic Plague and Health Interventions in Colonial Lagos' (2019). Moreover, the nascent development of the subfield of Nigerian health history is visible in the Doctor of Philosophy Degrees awarded by Nigerian Universities in the early twentyfirst century. Amongst the titles in this regard include Julius Akindele Oluyitan's 'History of Colonial Medical and Health Services in Ibadan, 1900-1960' (2014) and Olukayode A. Faleye's 'Historical Effects of the Bubonic Plague Epidemic in Lagos: 1924-1959' (2018b). While these studies agreed on certain grounds, the bifurcation of historical thought on the nature of colonial intervention in public health is once visible in these works. The scenario seems to agree with Collingwood that 'all history is the history of thought' (1946). Of course, all histories are historical theories built on selective facts (Murphey 1973). The notion of selective facts as used here implies the construction of historical accounts based on extant sources in line with the 
historian's pre-occupation with social, economic or political issues. Otherwise, the predetermined exclusion of inconvenient data implies a selective use of evidence which is inherently misleading. Certainly, historical narratives emanating from the latter confirms Polybius fear that 'partial histories are more or less useless when it comes to gaining a comprehensive perspective and are unreliable' (Polybius 2010: xxv). In advancing this discourse, Mary Fulbrook notes:

$[\mathrm{H}]$ istorical accounts are not simply narratives which are more or less arbitrarily imposed on (rather than found in or constructed from) selected traces of the past (whether this is deemed to be knowable or not), and are then presented in a form and style designed to achieve some sort of 'reality effect'. Against some empiricist positions... there are theoretical and conceptual choices which filter what historians working within different traditions of inquiry will look for by way of 'empirical evidence', which is not such a simple matter as many discussions of 'source criticism' might suggest... in this way it is possible to attain greater clarity about the bases for disagreements between different historical accounts; to clarify ways in which different theoretical and conceptual frameworks and associated substantial accounts can be operationalized, tested amended, or discarded; and/or to identify the respects in which they are rooted in essentially untestable propositions on which they may be accepted or rejected for metatheoretical, rather than substantive historical reasons. Thus, rather than wafting into vogue notions of multiple, simultaneous, competing perspectives among which one can only choose on grounds of personal preferences of one sort or another, or (worse) arguing the impossibility of any real sort of historical knowledge at all, it may be possible to develop a theoretically grounded notion of 'progress' in historical understanding (Fulbrook 2005: 30).

In the Nigerian experience, these are the explanatory dichotomies that project theoretical divisions along the Western triumphalist paradigm, racist-Afrocentric category, and the emerging critical synthesis. Rather than a weakness, these theoretical divisions elucidate historical reality shaped by the complexity of physical and social processes. Indeed, this complexity is particularly brought to light by the history of disease. The nomothetic triumphalist scientific theories have been undermined by the complexity of the disease environment and interventions. The antithesis has been particularly provided by the recrudes- 
cence of drug-resistant and multi-strain diseases (Patterson 1998). This phenomenon suggests a multiplicity of the universal existence that goes beyond a nomothetic theory of 'globality' but the complexity of 'glocality' evolving diseases strains conditioned by the divergent but co-productive nature and culture of the world.

The racist-Afrocentric category that began in the colonial era has been pre-occupied with the decolonisation of the writing of history. While this approach has contributed enormously to the emergence of new sources such as oral tradition and a new mode of interpretation, its often one-sided Afrocentric approach undermines its objectivity. This is often obvious in the discourse of colonial administration where the concept of colonialism is overly associated with the conspiracy to destroy, even when the reality in some events prove otherwise. For instance, post-colonialism has been preoccupied with the suppression of narratives that supposedly reinforces the official evidence in African History. In justifying this approach, Newell (2020: xv) lamented the supposed "whiting-out" of Africans from British colonial files, and the irretrievability of Afrophone audience from written midcentury media commentaries.' The postcolonial conspiracy approach to African Studies raises fundamental questions on the place of Africans in the writing of African history. In the context of historiography, should African historians write partial (incomplete, bias and unreliable) histories in defence of the African people? Scholars have long realized that the "academic who confused the values of religious commitment with the "value neutrality" ethic of scholarship' is 'dangerous' and betrays his or her 'intellectual integrity' (Dirk-Moses 2005b: 341). History is neither propaganda nor fiction and historical writings must be based on the available evidence both official and unofficial, irrespective of identity or philosophical affiliation.

While the passion to reconstruct a social history from 'below' is tantalizing, the validity of historical studies depends on the critical engagement with alternative theories. Certainly, 'history is not definitive... the historical reality lies in the amalgam of narratives' (Faleye 2020a: 580). Whereas the securitization of evidence justifies the use of extra-ordinary measures including the elimination of alternative hypotheses, this dogmatic methodology raises ethical questions: Could this approach provide a conduit for the plundering of extant historical writings in the name of decolonising historiography? Isn't this another dimension of intellectual imperialism at the forefront of the decolonisation movement in African Studies? If the answers to these questions are in the affirmative, chauvinism could metamorphose into criminali- 
ty. Beyond the simplistic conception of static colonial culture, history is a transition and transitions occurred even within the colonial epoch.

The development of the scientific element of historiography through statistical modelling of historical data, Cliodynamics and the application of Historical Geographical Information System (H-GIS) is particularly relevant in environmental and medical history. This approach separate historiography from the Pandora box of fiction and delimits the invasion of the discipline, after all, it is said; the historical archives are well catalogued and accessible to all. At the centre of this discourse is historical negationism and morality in historiography. As observed by Friedrich Nietzsche, morality is 'a surface phenomenon that requires meta-level interpretation in accordance with a different, superior set of extra-moral values "beyond good and evil"... Morality assumes knowledge of things it does not have' (Ansell-Pearson 2006: xvi-xvii). The idea of morality is relative and subjective. Hence, the demand for morality as opposed to ethics in historiography is a call on history to disappear into fiction. Amongst others, in the context of health history, the erroneous insinuation that fatality figures are sacred and should not be statistically modelled to unveil economic historical insights is a mandate that historians should stop thinking.

The need for historical utility with insights derived from the Western triumphalist paradigm and the racist-Afrocentric category has led to the emergence of critical synthesis. The issues of environmental health and virulent diseases bring to the fore the relevance of environmental and medical history amidst intellectual competitiveness across the arts and the sciences since the twentieth century. Environmental history is the study of the interactions between culture and nature. This implies a bilateral exchange that deals with the functionality, organisation and interaction between nature and human societies. To this end, it examines the relational complexity between the socioeconomic organisation of society and the natural environment with respect to technology, social relations and the system of production as well as the human interpretation of this phenomenon through social mechanisms of mythology, laws, ethics and so on (Worster 1988; Williams 1994). In this vein, the natural environment responds to human civilizations through global warming, natural disasters, diseases outbreak, etc. In essence, the bilateral interaction modifies human ideologies, policies and actions. In this light, environmental historians study climatic changes, geological transformations and disease processes using multidisciplinary approaches by adopting historical data and tools from ecology, biology, geography, forestry, meteorology, social sciences and so on (Smout 1993). Hence, it has been noted that the 
greatest intellectual disaster of the twentieth century is the separation of the arts from the sciences (Snow 1960). This disciplinary delineation means that scientists deal with nature and historians must focus on culture and society without taking cognizance of the co-production of existence between nature and culture (Worster 1993).

Environmental history connects nature back to the culture in the coproduction of holistic knowledge about humans and the physical world that straddles the boundaries of both the arts and the sciences (Isenberg 2014). This is particularly true in the study of disease processes, where the two sub-fields of environmental and medical history overlap into health history. Whereas medical history otherwise known as the history of medicine is the domain of the study of the historical transformation in medical knowledge and how societies responded to illness over time, the environmental historian in his study of diseases emanating from the nature-culture nexus operates in a shared borderland of environmental history and the history of medicine. Thus, in the study of the history of public health and disease processes, a respectable environmental historian is also a skilled medical historian. Of course, medical history as a multidisciplinary subfield of medicine and history emphasizes the importance of the medical thought of the past in connection with the 'provision of medical care'. This is obvious in the affirmation of the historical approach by the medical doctor each time he writes or speaks of the 'case history.' In respect of historical utility, the Environmental history of public health as well as the medical history rejects the idea of history for history sake but searches for alternative pathways of productive interaction with the environmental and medical practice of the present. This reality was articulated in the inaugural statement of the Journal of the history of medicine and allied sciences in 1946 that the discipline must live above historical approaches that failed to make history 'the living, dynamic thing,' as George Rosen puts it: 'we don't want to cultivate medical history as a mere search for antiquities as a kind of hunt for curious, but rather a vital, integral part of medicine' (Rosen 1946: 4). Corroborating the foregoing in his study of the history of disease pathology in India, Tirumurti observed:

'History of Medicine' is not a mere collection of dates and names. It attempts to describe ... how man reacted to his environments, and their unfavourable conditions, how he got over them and in what way his wounds were healed and ... diseases cured or prevented. A mere listing of the herbs or drugs, used in healing the sick, or of instruments, employed in surgery, is of no great value. It will be a catalogue, not history. The philosophy under medical thought in 
the successive epochs of man's history should be properly understood and explained (Tirumurti 1939: 226).

Further, environmental and medical history as specialised branches of the history of science is expected to project the 'institutions' aiding scientific research as well as the 'place' of scientific knowledge in 'changing social and economic structures' in society. Thus, it cannot be separated from the 'social context' that 'influences the formation and validation of scientific knowledge' (Palladino and Worboys 1993: 92). The study of these specialized areas of historical scholarship puts history at the intersectional boundary between the natural and social sciences as well as the arts and humanities. Thus, to practically reaffirm its 'self-acclaimed' place as a mediator between the disciplines, historians must engage more with the structural thoughts of other disciplines using historical evidence to test the tenets of existing theoretical assumptions, in the process, developing new logical thought patterns that reflect global distinctions, interconnectivity and similarities. What is the relevance of an isolated history that could not communicate the lessons of the past to other disciplines? The recognition of the evidence of the past as elemental in a wider chain of physical and social phenomenon is pertinent to historical explanation. As noted by Robin George Collingwood, 'the events of history are... things which the historian looks, not at, but through, to discern the thought within them' (Collingwood 1946: 214). This 'thought within them' as admissible in 'history' not 'psychology', perhaps indicates the explanation of historical facts beyond there surface narrative but with reflections on theoretical thoughts of auxiliary disciplines to enhance the production of an intelligible historical pattern in line with the societal movement in time, place, and space.

However, differing from the conventional approach, the historical study of public health and disease processes aggregate the social and material transformations that impact health with an outlook that accommodates the cultural basis of disease production both in the past and present (Nash 2014). How do we write the history of disease in Nigeria? The occurrence of natural environmental changes including industrialization and urbanization as well as discoveries in the field of medicine are well documented. It seems the role of the historian is to examine these processes in the light of disease causation. Further, it has been observed that in every medical action there are always two parties involved, the physician and the patient... Medicine is nothing else than the manifold relations between these two groups' (Sigerist 1936; Patterson 1998). Hence, it is the duty of the Nigerian health historian 
to examine the circumstances surrounding disease outbreaks and the ensued medical interventions - be it 'scientific' or 'traditional' and their relational complexity with the societal economy, social relations, and politics. Of course, this scope of historical inquiry pitches environmental and medical history with economic, social, and political history, however, from a more critical perspective. In essence, the environmental and medical historian adopts a mixed approach that embodies useful data and tools of analysis from other intersectional fields to illuminate the historical reality.

\section{CONCLUDING REMARKS}

In sum, this article examined the contributions of the historical explanation of disease to the writing of Nigerian history. It reveals the trend of Nigerian historiography and its challenges from a 'glocal' perspective. It shows that in the search for historical utility, the environmental and medical pathways encourage the development of a fortified and rigorous account of the fragmentary evidence of the past that take cognizance of the interests and insights of the present and its dialogue with the past. While massive documentation on public health and disease processes lie dormant in the Nigerian colonial archives, these sources could form a basis of new insights into African History. Moreover, the native language print archive (vernacular press) provides a unique insight into the African discourse on disease and public health in colonial Nigeria. In the post-colonial era, the extant oral histories and print media on disease and health could be tapped for historical reconstruction. Also, the emerging scientific literature on diseases such as AIDS, Ebola, cancer, and Lassa fever indicates grey areas for contemporary research in the environmental and medical history of Nigeria from the public health perspective. In this light, the historian is connected with the ongoing debate in the sciences while projecting its narrative in analytical sophistication. In this way, Nigerian historiography informs both arts and the sciences, thereby fulfilling its utilitarian obligations as a medium that studies the past in the interest of the present.

\section{REFERENCES}

Adeoye, A. O. 1992. Understanding the Crisis in Modern Nigerian Historiography. History in Africa 19: 1-11.

Aderinto, S. A. 2012. Dangerous Aphrodisiac, Restless Sexuality: Venereal Disease, Biomedicine, and Protectionism in Colonial Lagos'. Journal of Colonialism and Colonial History 13 (3): DOI: 10.1353/cch.2012.0043.

Adesoji, A. O. 2006. Globalization of the Media and the Challenges of Democratisation in Nigeria. Nebula 3 (4): 38-50. 
Ajayi, J. F. A. and Smith. R. S. 1979. Yoruba Warfare in the Nineteenth Century. Cambridge: Cambridge University Press.

Ake, C. E. 1979. Social Science as Imperialism: The Theory of Political Development. Ibadan: Ibadan University Press.

Akinrinade, S. and Ogen, O. 2008. Globalization and De-industrialization: South-South Neo-liberalism and the Collapse of the Nigerian Textile Industry. The Global South 2 (2): 159-170.

Alagoa, E. J. 1964. The Small Brave City-State: A History of Nembe-Brass in the Niger Delta. Ibadan: University Press.

Anene, J. C. 1970. The International Boundaries of Nigeria, 1885-1960: The Framework of an Emergent African Nation. London: Longman.

Ansell-Pearson, K. (ed.). 2006. Friedrich Nietzsche: On the Geneology of Morality. Cambridge: Cambridge University Press.

Atanda, J. A. 1973. The New Oyo Empire: Indirect Rule and Change in Western Nigeria, 1894-1934. London: Longman.

Bell, D. S. A. 2005. Dissolving Distance: Technology, Space, and Empire in British Political thought, 1770-1900. The Journal of Modern History 77 (3): 549-550.

Bentrovato, D., Korostelina, K. V., and Schulze, M. (eds.) 2016. History Can Bite: History Education in Divided and Postwar Societies. Gottingen: V\&R Unipress.

Bigon, L. 2015. Bubonic Plague, Colonial Ideologies, and Urban Planning Policies: Dakar, Lagos, and Kumasi. Planning Perspectives. URL: http:// dx.doi.org/10.1080/02665433.2015.1064779.

Brown, S. H. 1992. Public Health in Lagos, 1850-1900: Perceptions, Pattern, and Perspectives. The International Journal of African Historical Studies 25 (2): 337-360.

Brown, S. H. 2004. A Tool of Empire: The British Medical Establishment in Lagos, 1861-1905. The International Journal of African Historical Studies 37 (2): 309-343.

Carr. E. H. 1961. What is History? London: Penguine.

Cohn, B. S. 1996. Colonialism and its Forms of Knowledge: The British in India. Princeton University Press.

Collingwood, R. G. 1946. The Idea of History. Oxford: Oxford University Press.

Dike, K. O. 1956. Trade and Politics in the Niger Delta, 1830-1885: An Introduction to the Economic and Political History of Nigeria. Oxford: Clarendon Press.

Dirk-Moses, A. 2005a. Hayden White, Traumatic Nationalism, and the Public Role of History. History and Theory 44 (3): 311-332.

Dirk-Moses, A. 2005b. The Public Relevance of Historical Studies: A Rejoinder to Hayden White. History and Theory 44 (3): 339-347. 
Eyinla, B. M. 1999. The ODA Charter and Changing Objectives of Japan's Aid Policy in Sub-Saharan Africa. The Journal of Modern African Studies 37 (3): 409-430.

Eyinla, B. M. 2000. The Tokyo Agenda for Action: A Review of Japan's New Strategy on African Development. Africa Spectrum 35 (2): 217-229.

Eyinla, B. M. 2004. Beyond Cairo: Emerging Pattern of Euro-African Relationship. Africa 59 (2): 159-178.

Faleye, O. A. 2014. Africa and International Relations Theory: Acquiescence and Responses. Journal of Globalization Studies 5 (2): 81-90.

Faleye, O. A. 2016. Regional Integration from 'Below' in West Africa: A Study of Transboundary Town-Twinning of Idiroko (Nigeria) and Igolo (Benin). Regions \& Cohesion 6 (3): 1-8.

Faleye, O. A. 2017. Environmental Change, Sanitation and Bubonic Plague in Lagos, 1924-31. International Review of Environmental History 3 (2): 89-103.

Faleye, O. A. 2018a. Plague and Trade in Lagos, 1924-1931. International Journal of Maritime History 30 (2): 287-301.

Faleye, O. A. 2018b. Historical Effects of the Bubonic Plague Epidemic in Lagos: 1924-1959. Ph.D Thesis, Department of History and International Studies, University of Ilorin.

Faleye, O. A. 2020a. Histories of Dirt: Media and Urban Life in Colonial and Postcolonial Lagos. Canadian Journal of African Studies / Revue canadienne des études africaines 54 (3): 579-581, DOI: 10.1080/00083968.2020. 1821938.

Faleye, O. A. 2020b. International Relations Theory: Comparative Reflections on EU-Africa Relations. In Haastrup, T., Mah, L. and Duggan, N. (eds.), Routledge Handbook of EU-Africa Relations (pp. 14-25). London: Routledge.

Faleye, O. A., and Akande, T. M. 2019. Beyond 'White Medicine': Bubonic Plague and Health Interventions in Colonial Lagos. Gesnerus: Swiss Journal of the History of Medicine and Sciences 76 (1): 90-110.

Falola, T. 1981. Trends in Nigerian Historiography. Transafrican Journal of History 10 (1/2): 97-112.

Falola, T. and Aderinto, S. 2010. Nigeria, Nationalism, and Writing History. Rochester: University of Rochester Press.

Fulbrook, M. 2005. Historical Theory. London and New York: Routledge.

Gandy, M. 2006a. The Bacteriological City and Its Discontents. Historical Geography 34: 14-25.

Gandy, M. 2006b. Planning, Anti-planning and the Infrastructure Crisis Facing Metropolitan Lagos. Urban Studies 43 (2): 371-396.

Gandy, M. 2008. Landscapes of Disaster: Water, Modernity, and Urban Fragmentation in Mumbai. Environment and Planning A 40: 108-130. 
Home, R. K. 1938. Town Planning, Segregation and Indirect Rule in Colonial Nigeria. Third World Planning Review 5 (2): 165-175.

Home, R. K. 1990. Town Planning and Garden Cities in the British Colonial Empire 1910-1940. Planning Perspectives 5 (1): 23-37.

Home, R. K. 2013. Of Planting and Planning: The Making of British Colonial Cities. $2^{\text {nd }}$ ed. London: Routledge.

Isenberg, A. C. (ed.). 2014. The Oxford Handbook of Environmental History. Oxford: Oxford University Press.

Johnson, S. 1921. The History of the Yorubas. From the Earliest Times to the Beginning of the British Protectorate. London: CMS.

Macleod, R. 1993. Passages in Imperial Science: From Empire to Commonwealth. Journal of World History 4 (1): 117-150.

Murphey, M. G. 1973. Our Knowledge of the Historical Past. Indianapolis: Bobbs-Merrill.

Nash, L. 2014. Beyond Virgin Soils: Disease as Environmental History. In Isenberg, A. C. (ed.), The Oxford Handbook of Environmental History (pp. 76-107). Oxford: Oxford University Press.

Newell, S. 2020. Histories of Dirt: Media and Urban Life in Colonial and Postcolonial Lagos. Durham: Duke University Press.

Oduntan, O. B. 2017. Culture and Colonial Medicine: Smallpox in Abeokuta, Western Nigeria. Social History of Medicine 30 (1): 48-70.

Oduwobi, T. 2013. Tackling Leprosy in Colonial Nigeria, 1926-1960, Journal of the Historical Society of Nigeria 22: 178-205.

Olaniyan, R. A., and Akinyele, R. T. (eds). 2016. Nigeria's Ungoverned Spaces: Studies in Security, Terrorism and Governance. Ile-Ife: Obafemi Awolowo University Press.

Olukoju, A. 1993. Population Pressure, Housing and Sanitation in West Africa's Premier Port-City: Lagos, 1900-1939. The Great Circle 15 (2): 91-106.

Oluwasegun, J. M. 2015. Managing Epidemic: The British Approach to 1918-1919 Influenza in Lagos. Journal of Asian and African Studies. DOI: 0021909615587367.

Oluwasegun, J. M. 2017.The British Mosquito Eradication Campaign in Colonial Lagos, 1902-1950. Canadian Journal of African Studies 51 (2): $217-236$.

Oluyitan, J. A. 2014. History of Colonial Medical and Health Services in Ibadan, 1900-1960. PhD thesis. Department of History, University of Ibadan.

Palladino, P., and Worboys. M. 1993. Science and Imperialism. Isis 84 (1): 91-102.

Patterson, J. T. 1998. How Do We Write the History of Disease? Health and History 1 (1): 5-29. 
Polybius. 2010. The Histories. Translated by Waterfield R. Oxford: Oxford University Press.

Pyenson, L. 1993. Cultural Imperialism and Exact Sciences Revisited. Isis 84 (1): 103-108.

Pyenson, L., and Pyenson, S. 1999. Servants of Nature: A History of Scientific Institutions, Enterprises and Sensibilities. New York and London: WW. Norton and Company.

Reingold N., and Rothenberg, M. (eds). 1987. Scientific Colonialism: A CrossCultural Comparison. Washington, D. C.: Smithsonian Institution Press.

Robertson, R. 1995. Glocalization: Time-Space and Homogeneity - Heterogeneity. In Featherstone, M., Lash, S., and Robertson, R. (eds), Global Modernities (pp. 25-44). London: Sage.

Rosen, G. 1946. What is Past, is prologue. Journal of the History of Medicine and Allied Sciences 1 (1): 3-5.

Shaw, T. 1963. Field Research in Nigerian Archaeology: A Brief Survey and Discussion of Policy. Journal of the Historical Society of Nigeria 2 (4): 449-464.

Sigerist, H. 1936. The History of Medicine and the History of Disease. Bulletin of the Institute of the History of Medicine 4: 1-13.

Smout, T. C. (ed.). 1993. Scotland since Prehistory: Natural Change and Human Impact. Aberdeen.

Snow, C. P. 1960. The Two Cultures and the Scientific Revolution. Cambridge: Cambridge University Press.

Tirumurti, R. T. 1939. A Brief Account of the History of Pathology. Proceedings of the twenty-sixth Indian Science Congress, Lahore.

Webb, J. L. A. 2013. Historical Epidemiology and Infectious Disease Processes in Africa. The Journal of African History 54 (1): 3-10.

White, H. V. 1966. The Burden of History. History and Theory 5 (2): 111-134.

White, H. 2005. The Public Relevance of Historical Studies: A Reply to Dirk Moses. History and Theory 44 (3): 333-338.

White, H. V. 2014. Metahistory: The Historical Imagination in NineteenthCentury Europe. JHU Press.

Williams, M. 1994. The relations of Environmental History and Historical Geography. Journal of Historical Geography 20 (1): 3-21.

Worster, D. (ed.) 1988. The Ends of the Earth: Perspectives on Modern Environmental History. Cambridge: Cambridge University Press.

Worster, D. 1993. The Wealth of Nature: Enironmental History and Ecological Imagination. Oxford: Oxford Univeristy Press. 